\section{Van Yüzüncü Yıl Üniversitesi Kampüs Yerleşkesi Kıyı Alanında Peyzaj Planlama Örneği}

Van Yüzüncü Y1l University Campus Landscape Planning in Case of Coastal Areas

Nursevil YUCA ${ }^{1}$

Feran AŞUR ${ }^{2}$
Strategic Public Management Journal Volume 7, Issue 13, pp. 78-89

May 2021

DOI: 10.25069/spmj.810697

Research Article/Araştırma Makalesi Received: 14.10.2020 Accepted: 07.05.2021

(C) The Author(s) 2021 For reprints and permissions: http://dergipark.gov.tr/spmj

$\ddot{O} z$

Üniversite kampüsleri birer eğitim kurumu olmalarlyla birlikte önemli sosyal ve kültürel mekânlardır. Bu alanlar; farklı kültür, sosyal ve etnik yapılara sahip öğrencilerin eğitim süreçleri boyunca ders dışı zamanlarının büyük dilimini geçirdikleri mekânlar olup eğitimciler ve çalışanlar için de sosyal etkileşim açışından büyük önem taşımaktadırlar. Bu nedenle üniversite yerleşkelerinin planlamalarında birçok faktörü göz önünde bulundurmak gerekir. Peyzaj planlama, Avrupa Peyzaj Sözleşmesi tanımına göre; peyzajların geliştirilmesi, iyileştirilmesi ve oluşturulması amaçlı geleceğe yönelik güçlü eylemlerdir. Buna paralel olarak, çeşitli başlıklar altında peyzajların sürdürülebilir planlanmasının öneminden söz etmiştir.

Bu çalışmada Van ilinde, Van Gölü’ne klyısı olan Yüzüncü Yıl Üniversitesi kampüs sınırlarında klyı alanında seçilen bir alanın kıyı kullanım ilişkilerini inceleyerek peyzaj planı önerisinde bulunulmuştur. Bu anlamda kampüs alanının kullanım amaçları, kullanıcı beklentileri, kıyı kullanımına ilişkin olumlu-olumsuz faktörler gibi konular ele anılarak yapılan değerlendirmeler sonucu peyzaj planı geliştirilmiştir. Bu model kıyı peyzaj planlamasına yol gösterici birer araç olarak kullanılması düşünülmektedir.

Anahtar Kelimeler: Kampüs peyzajı, Kıyı planlama, Van Yüzüncü Yıl Üniversitesi.

\title{
Abstract
}

Along with university campuses are educational institutions, they are important social and cultural places. These areas are; They are places where students with different cultural, social and ethnic backgrounds spend most of their extracurricular time during their education process and are of great importance for educators and employees in terms of social interaction. For this reason, it is necessary to consider many factors in the planning of university campuses. Landscape planning is according to the definition of the European Landscape

\footnotetext{
${ }^{1}$ Arş. Gör., Van Yüzüncü Yıl Üniversitesi Mimarlık ve Tasarım Fakültesi, Peyzaj Mimarlığı Bölümü, nursevilyuca@yyu.edu.tr, ORCID ID: 0000-0002-7985-7706.

${ }^{2}$ Doç. Dr., Van Yüzüncü Yıl Üniversitesi Mimarlık ve Tasarım Fakültesi, Peyzaj Mimarlığı Bölümü, feranekasur@gmail.com ORCID ID: 0000-0001-9480-5536.
} 
Convention; Strong actions for the future aimed at developing, improving and creating landscapes. Parallel to this, he mentioned the importance of sustainable planning of landscapes under various titles.

In this study, a landscape plan was proposed by examining the coastal use relations of an area selected in the coastal area of the Yüzüncü Yll University campus in the province of Van, on the coast of Lake Van. In this sense, the landscape plan was developed as a result of the evaluations made by discussing the usage purposes of the campus area, user expectations, positive and negative factors regarding the use of the coast. This model is thought to be used as a guiding tool in coastal landscape planning.

Keywords: Campus landscape, Coastal planning, Van Centenary University.

\section{GİRIŞ}

Üniversitesi 1982 yılında kurulmuş olup öğretim faaliyetleri ilk olarak kent merkezindeki birkaç binada başlamıştır. Üniversite yerleşkesinde bugün çok sayıda fakülte ve yüksekokul binası ile yemekhane, idari spor tesisi vb. amaçlarla kullanılan yapılar yer almaktadır. Ayrıca Kredi Yurtlar Kurumu'na bağlı yurt binaları da Van YYÜ Yerleşkesi ile bitişik durumdadır. 2011 yılında ise üniversite ile organize sanayi bölgesi arasında YYÜ Tıp Fakültesi Araştırma Hastanesi yapılmaya başlanmıştır. 2012 yılında Van YYÜ Yerleşkesi içinde 500 adet lojman ve 13 yeni yurt binası inşa edilmiştir (Şekil 1).

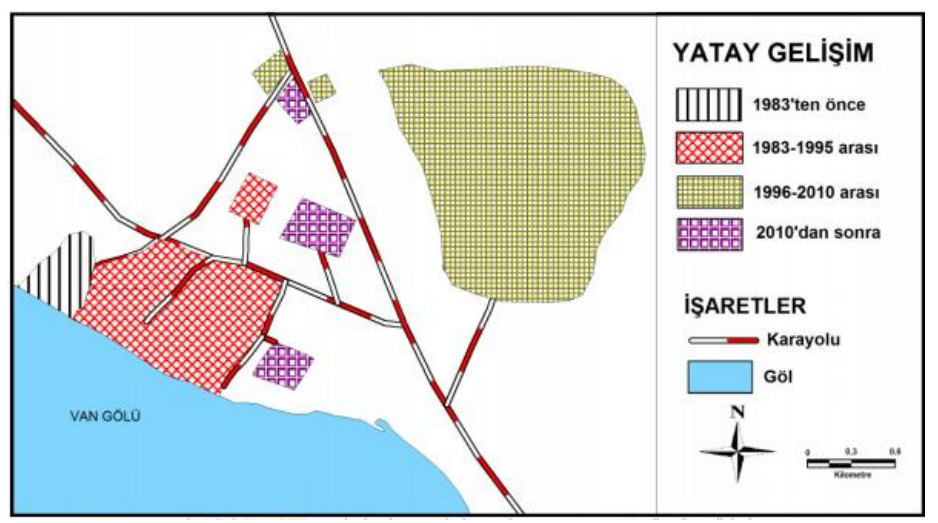

Şekil 1.Van YYÜ yerleşkesi çevresinde yapılaşmanın yatay (tarihsel) gelişimi (Yılmaz,2014).

Figure 1. Horizontal (historical) development of the construction around the Van YYÜ campus (Y1lmaz, 2014).

Van YYÜ Zeve Kampüs, inceleme alanı ve yakın çevresinin mekânsal kurgusu Van Gölü'nün kıyı morfolojisi ile biçimlendirilen kampüs-kıyı ilişkisidir. Kampüs içinde fakülte binaları çok yakın olmasa da yakın zamanda yapılan ve ana yolun bir parçası olan ulaşım hattının inceleme alanının kıyısına yakın, yer yer kıyı kenar çizgisine dokunan bir mesafeden geçtiği görülmektedir. Bu durum kıyı alanını korumasız bırakabilmektedir. Van YYÜ Kampüsü yaklaşık 2600 m kıyı uzunluğuna sahip olup, uygun koşulları ile bir süredir birçok su sporuna ev sahipliği yapmaktadır. $500 \mathrm{~m}$ uzunluğundaki taş dolgu kıyı şeridi boyunca düzenlenmiş yürüyüş yolları, banklar, yeşil alan ve göl üzeri kameriyeler bulunmaktadır (Şekil 2). Sonradan yapılmış olan taş dolgu iki iskelenin her iki tarafında, futbol ve voleybol sahası olarak da kullanılan kumsal alanın iç kısımlarla arasındaki kot farkı, su sporları kabinleri ile desteklenmiştir. 


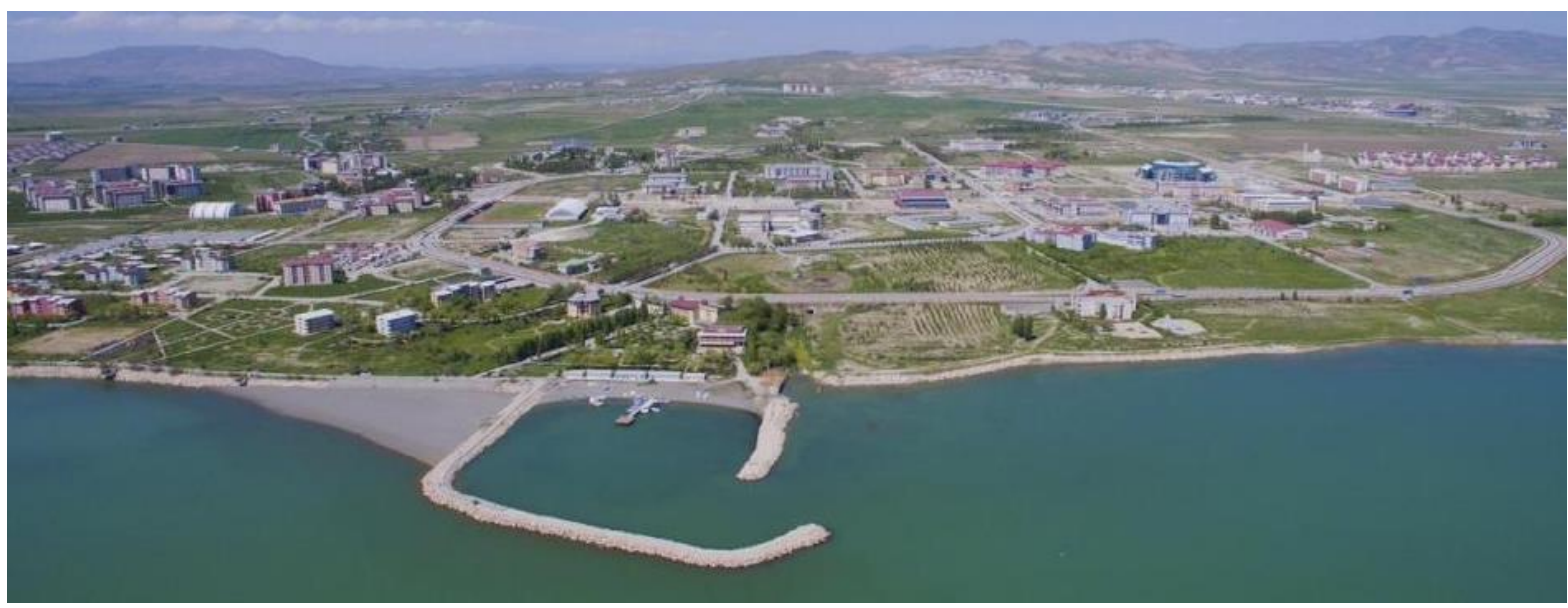

Şekil 2. Van YYÜ Kampüsü kıyı görüntüsü (URL 2, 2020)

Figure 2. Van YYÜ Campus shore view (URL 2, 2020)

\section{MATERYAL VE METOT}

\subsection{Materyal}

Çalışmanın ana materyali Tuşba ilçesine bağlı olan Van YYÜ Kampüsü kıyısında seçilen alandan oluşmaktadır (Şekil 3). Van Yüzüncü Y1l Üniversitesi Zeve Kampüsü’nün güneydoğu yönünde kalan ve kampüs kıyısının büyük bölümünü içinde bulunduran inceleme alanı yaklaşı 460 dekar olup, batısında sosyal tesis, doğusunda Maden Tetkik ve Arama Müdürlüğü, geri kalan yönlerde yollarla sınırlıdır. Sahilin büyük kısmını oluşturan yaklaşık 1700 m uzunluğundaki kıyı, çalışma alanının sahilini kapsamaktadır ve büyük ölçüde doğal yapısı ile bırakılmıştır. Alanın kuzey tarafında üniversite personelinin kullanabildiği hobi bahçeleri mevcuttur. Bahçeye yakın mesafelerde kavak (Populus sp.), akasya (Robinia sp.) ve söğüt (Salix sp.) türleri mevcuttur. Geri kalan kısım boş bırakılmıştır. İnceleme alanında kıyıya doğru sazlık ve bataklık kesimler mevcuttur. Sazlıklar ile göl arasında taşlık barındıran bir kum seddi bulunmaktadır. Bu göl, kumsal ve bataklık alanları pek çok kuş türünün beslenme, dinlenme ve göç yeri olarak önem kazanmakta, biyoçeşitliliğin oluştuğu diğer türlere de ev sahipliği yapmaktadır. Sazlık alanlardaki bitkilerin ise daha çok kamış (Phragmites australis) türleri olduğu görülmektedir. Alanın batı yönünde bulunun sosyal tesisin yanından yaklaşık 100 metre mesafeye kadar olan bölümde 7-8 yıl önce dikilmiş olan sıralı meyve ağaçları, geri kalan bölgede ise dağınık halde yer yer kavak ağaçları görülmektedir. 


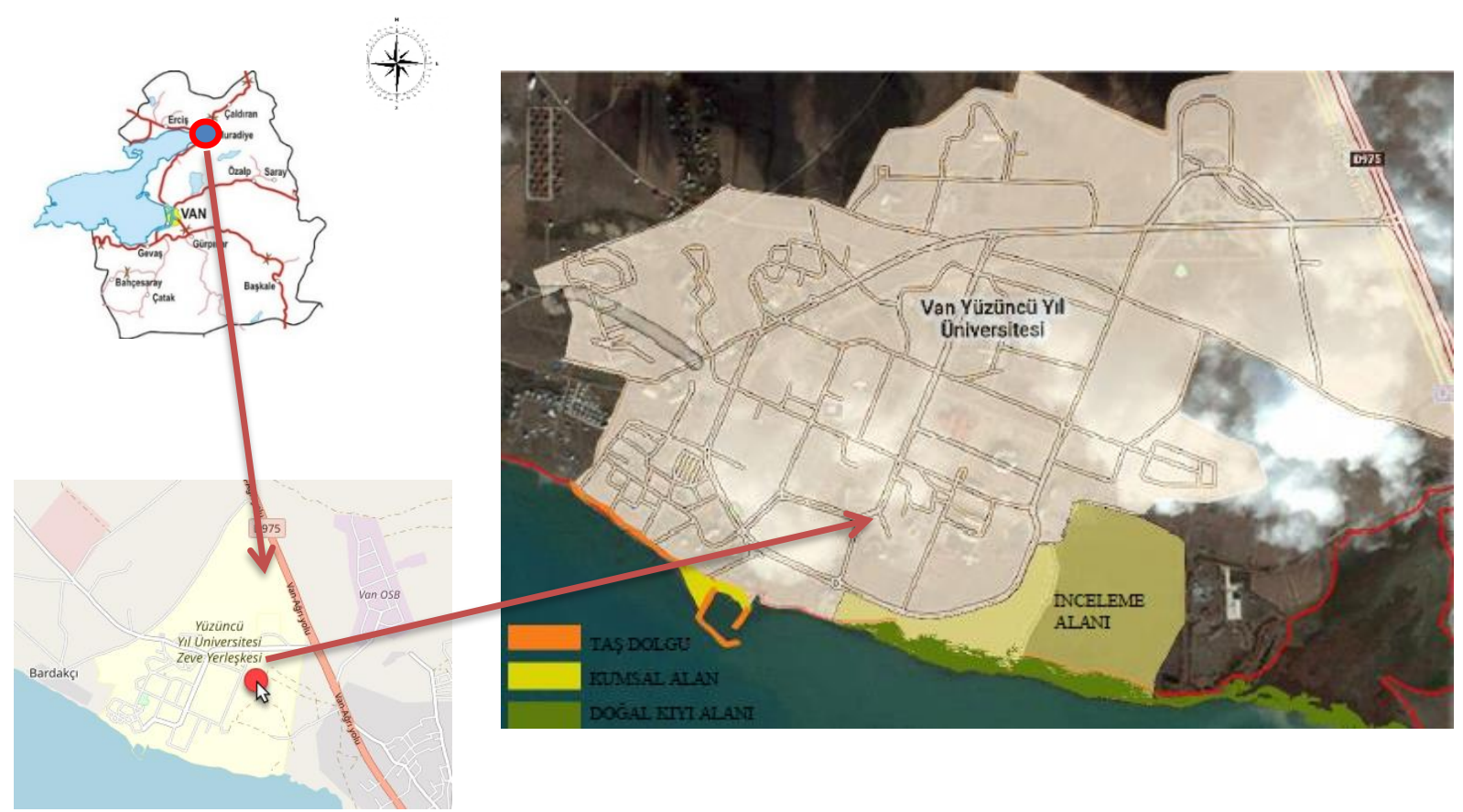

Şekil 3. Van YYÜ kampüsünde kıyı morfolojisi ve çalışma alanı (Google Earth Pro, 2020)

Figure 3.Shore morphology and study area in Van YYÜ campus (Google Earth Pro, 2020)

\subsection{Metot}

Alanla ilgili envanter hazırlamasında önceki çalışmalar ve literatür taraması yapılarak alan hakkında bilgiler elde edilmiştir. Peyzaj planı yapılacak alanda yerinde inceleme ve gözlem yapılmış, fotoğraflar çekilmiş, öğrenciler ve çalışanlarla sözlü görüşmeler yapılmıştır. Öneri peyzaj planın hazırlanmasında çeşitli çizim programlarından yararlanılmıştır. Çalışmada kullanılan yöntem 3 ana aşamadan oluşmaktadır: Birinci aşamada alanın mevcut kullanımlarını ve ihtiyaç listesinin belirlenmesine yönelik değerlendirmeler, alanın mekânsal, ulaşım ağı, iklim ve bitki örtüsü, kıyı analizi ve jeolojik yapısı ve görsel analizi yapılmıştır (Yı1maz ve Yılmaz, 2000; Bekci, et al., 2013; Açıksöz vd., 2014; Aşur ve Alphan, 2018). İkinci aşamada peyzaj planı projesinin ana kararları belirlenmiştir (Booth 1990). Üçüncü aşamada çalışma alanının verileri dikkate alınarak öneri peyzaj planı geliştirilmiştir.

\section{BULGULAR}

Van Yüzüncü Yı1 Üniversitesi Kampüs yerleşkesindeki çalışma alanına yönelik geliştirilen çözüm önerilerinin değerlendirilmesi öneri peyzaj planı gelişmesinin temelini oluşmuştur. Seçilen bu kıyı alanı kampüste araç yoluna yakın ancak fakültelerden biraz uzak ve kıyıya yakın durumda olduğu için dinlenme olanağı sağlayabilen bir bölge niteliğindedir. Ancak şimdiye kadar hiçbir düzenlemeye tabi tutulmayan bir alan konumundadır. Zaman zaman gezmeye gelen öğrencilerle görüşmeler sonucunda bu bölgeyi gezmek için uygun bulduklarını ancak plansızlık ve çevre düzenleme yetersizliği nedeniyle burayı daha az tercih ettiklerini dile getirmişlerdir. Van Yüzüncü Yıl Üniversitesi öğrencilerine eğitim, öğretim dışında kıyı alanında da daha 
kaliteli sosyal ve kültürel olanaklar sunabilmek amacıyla ön görülen peyzaj planı için yerleşke alanında mekânsal bilgileri, ulaşım ağı, kıyı analizi, iklim ve bitki örtüsü, jeolojik yapısı ile görsel analiz ilgili ortaya konulan bilgiler Şekil 4 ve Tablo 1'de kısaca ele alınmıştır. Ayrıca alandaki rüzgar yönü ve gürültü kirliliği tespiti yapılmıştır. Peyzaj planı yapılacak alanda arazi gözlemleri yapılarak farklı bakış noktalardan peyzajın görsel değerleri incelenme yapılarak fotoğraflar çekilmiştir (Şekil 4). Doğal öğelerden sulak alanlar ve sazlık alanların görüntüleri de görsel değerleri olan peyzajlardır (Aşur, 2017). Bu bağlamda alanda bakış noktalarında yer alan etkin manzaralar tespit edilmiştir. Hem doğal (göl kıyısı, dağ ve sazlık alan gibi) hem kültürel (alanın tam karşısındaki tarihi Van Kalesi, kampus alanı içindeki yapısal elemanlar gibi) öğeler içeren manzaralar tespit edildiği için planlamayı da bu peyzajların kullanıcı tarafından görünmesini sağlayacak şekilde yapılması öngörülmüştür.

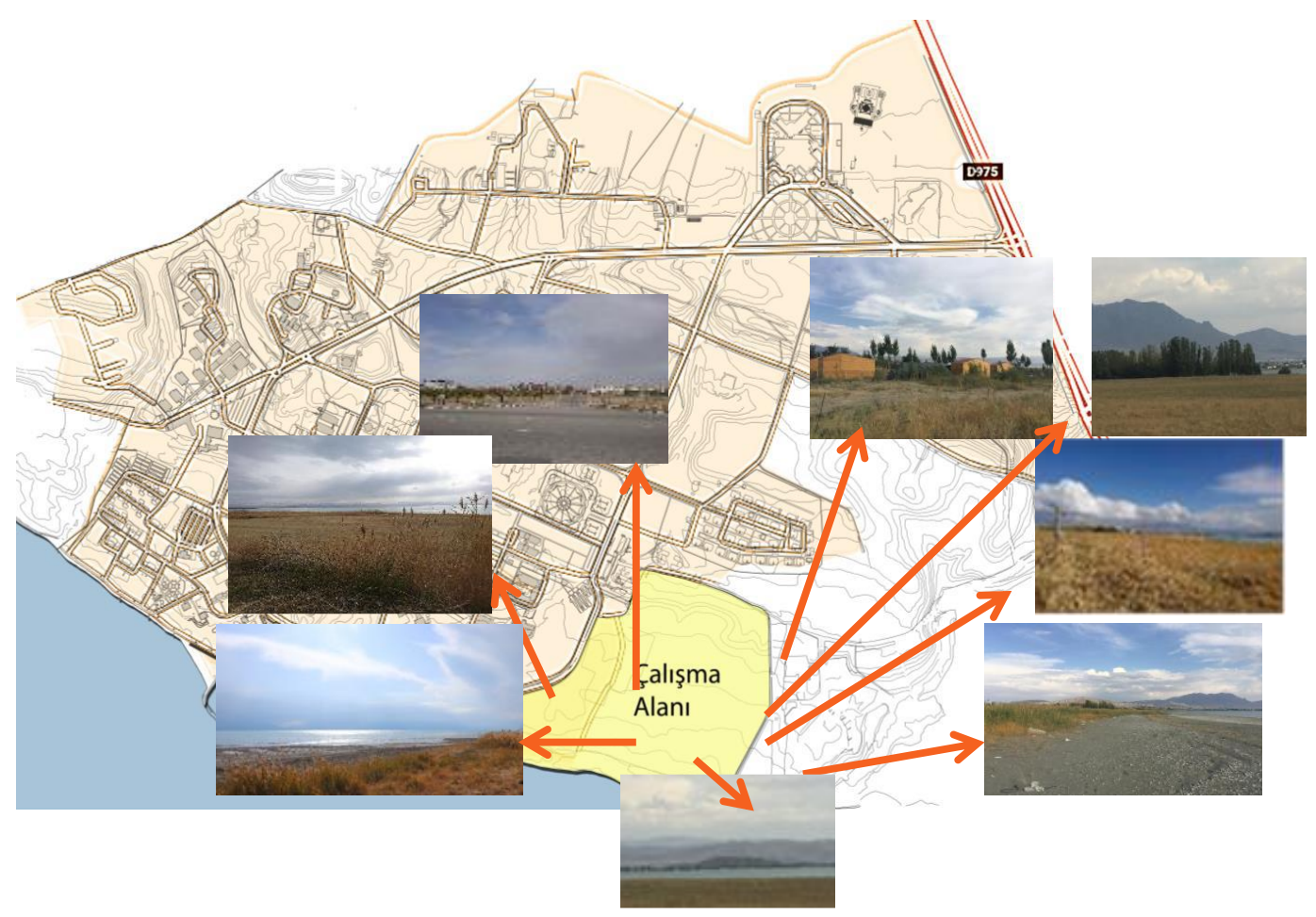

Şekil 4. Çalışma alanının görsel değerleri

Figure 4. Visual values of the work area 
Table 1. Examination of Van Yüzüncü Y1l University Zeve Campus Field Analysis

Çizelge 1. Van Yüzüncü Yıll Üniversitesi Zeve Yerleşkesi Alan Analizleri İrdelenmesi

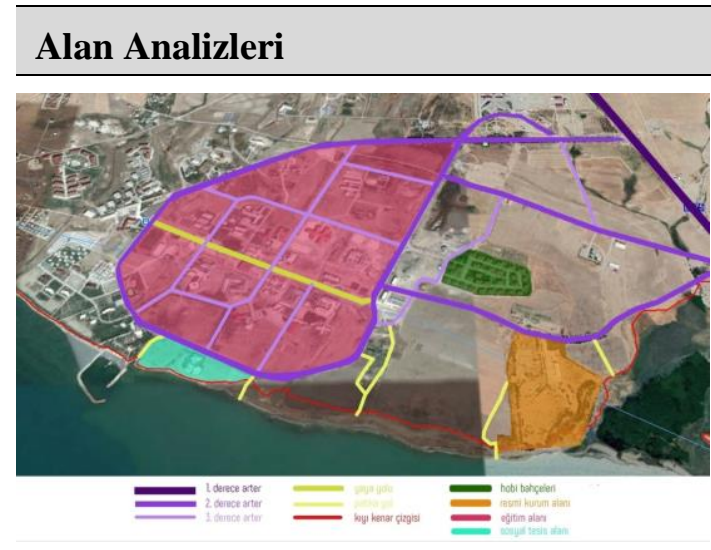

Mekansal Bilgiler

Van YYÜ kampüsü, 8500 hektar genişliğinde kampüs alanı ile Van Gölü'nün doğusunda, Van il merkezinin kuzeybatısında yer almaktadır. Van YYÜ Kampüsü yaklaşık 2600 m kıyı uzunluğuna sahiptir. Kampüs alanı, batıda Bardakçı köy yolu, doğuda Maden Tetkik Arama Doğu Anadolu Bölge Müdürlüğü ve Erciş - Van karayolu, güneyde ise Van Gölü ile sinırlanmaktadır.

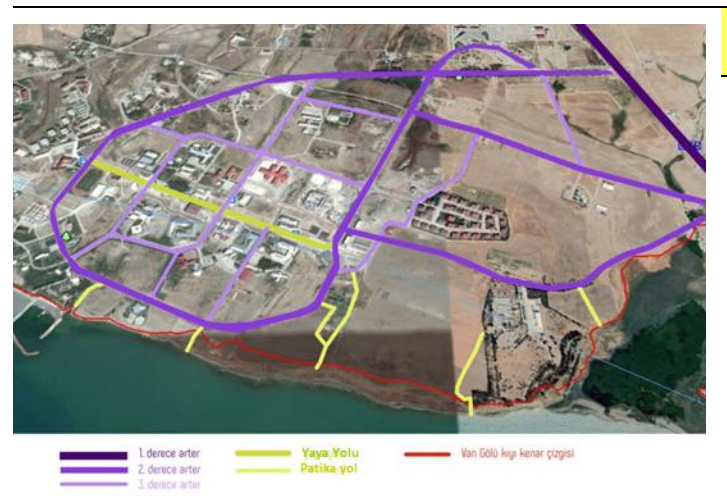

Ulaşım A

Van YYÜ Kampüs alanı Van- Erciş karayolu üzerinde bulanmaktadır. Kampüs kavşağının 4 km kuzeyinden şehir merkezine kadar yaklaşık 15 km'lik karayolu bağlantısı ile ulaşım sağlanmaktadır. Van YYÜ kampüs alanı içinde ise fakülteler ve birimler arasında ana arterlerde araç yolları ve yaya yolları ile ulaşım gerçekleşebilmektedir.

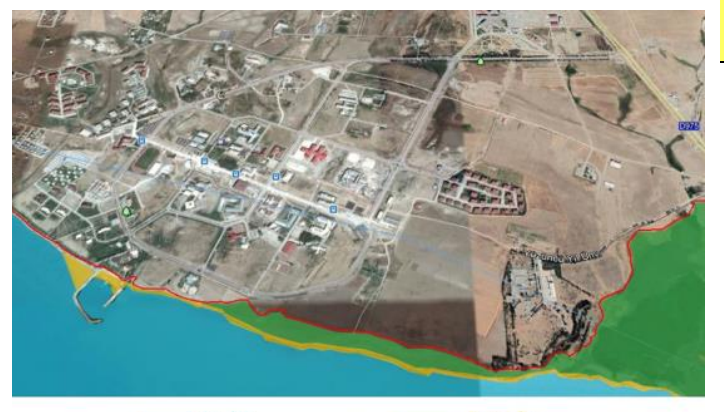

Kıy Analizi

Van YYÜ yerleşkesi ve yakın çevresi Van Gölü'nün kıyısında yer almaktadır. Van Gölü'nün seviyesi Pleistosendeki Würm buzul çağında 70-72 m. kadar yükselmiştir (Atalay, 2005). İnceleme alanının da içinde bulunduğu ve o dönemde göl suları tarafından işgal edilen alanlar alüvyal dolguya maruz kalmıştır. Bu nedenle bu sahanın yapılaşmaya elverişli değildir. Kıyı alanında küçük sulak alanlar ve kumul alan bulunmaktadır.

İklim ve Bitki örtüsü

Van Bölgesinde Akdeniz ve Karasal yağış rejimleri arasında geçiş tipi bir yağış rejimi görülür. Van yılın 120 günü açık 200 günü bulutlu ve 45 günü ise kapalı gün özelliği ile Türkiye'nin en fazla güneş alan illerinden biridir. Kampüs alnında kültür bitkileri 


\section{bulunmakla beraber, çalışma alanında gölün tuzlu ve sodalı etkisiyle bitki örtüsü sınırlıdır (URL 3, 2020).}

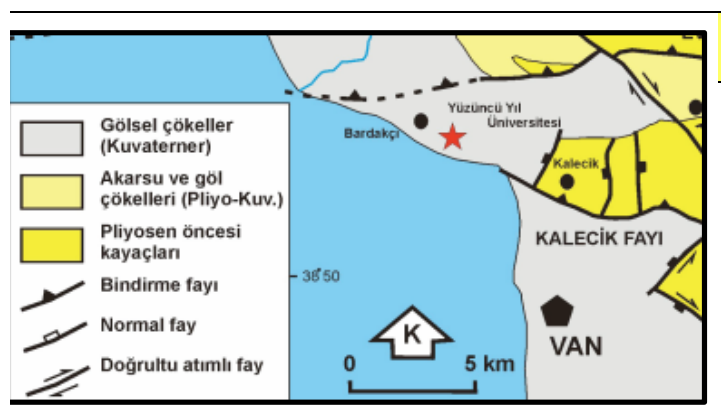

Jeolojik yapısı

Yüzüncü Yıl Üniversitesi kampüs alanı

Kuvaterner yaşlı eski gölsel çökeller üzerinde yer almaktadır. Eski göl çökellerinin toplam kalınlığı yaklaşık 150 metredir (Acarlar vd., 1991). Önceki çalışmalara göre, kampüs alanında eski göl çökellerinin yanında eski akarsu çökelleri ile güncel akarsu çökellerine de rastlanılmıştır (Acarlar vd., 1991; Selçuk, 2003; Koçyiğit, 2013; Akın vd., 2015).

\section{1. Öneri Peyzaj Plan Kararları}

Van YYÜ kıyı bölgesinde seçilen alan için yapılan analizler sonucunda öneri plan karaları aşağıdaki gibi hazırlanmıştır.

- Kıyı şeridinin tümüne (kıyı kenar çizgisinden en az 50 m derinliğe kadar) ekolojik koruma bölgesinin belirlenmesi,

- Kıyı şeridinin batı yönündeki kısmına ahşap yürüyüş ve seyir iskeleler,

- Kıyı şeridinin doğu yönündeki sazlık ve kumsal alanlar kuş gözlemleri, foto-safari, doğa gezileri, dinlenme, seyir gibi çeşitli doğa aktiviteleri; ayrıca ilgili fakülte ve birimlerin de doğal laboratuvar olarak kullanımına imkân sağlayan alanların sağlanması,

- Kıyı şeridinin kuzeyinde, alanın doğusunda bulunan bölgede, doğal bitki örtüsü ile bitkilendirmenin yapılmas1,

- Doğal malzemelerin kullanıldığı kentsel mobilyaların olduğu rekreasyon alanları,

- Mevcut hobi bahçelerinin alanı kııı şeridine doğru genişletilmesi,

- Alanın doğusunda, rekreasyon alanının kuzeyinde bulunan alanda Ziraat Fakültesi Tarımsal Uygulama ve Araştırma Alanı,

- Tiyatro ve müzik için alnın odak noktasında platform oluşturması (amaç sanat eğitimi gören ögrencilerin çalışmalarını sergileyebilecekleri alanı oluşturmaktır),

- Mevcut yol girişi kullanılarak yaya ve bisiklet yolu, yaya yolu geniş tutularak içerisinde oturma birileri ile yeşil bantların oluşturması,

- Öğrencilere hitap edecek kapsamlı kafeterya yapılması,

- Kıyı bandını kullanılabilmesi için bisiklet yolu ve öğrencilerin gelir elde edebilmeleri için yaptıkları eskiz, portre, heykel satışlarının gerçekleştirebilecekleri platformların oluşturması

- Sergi için alanına gelecek bireylere otopark alanı yapımı, ön görülmüştür. 


\subsection{Planlama Önerisi}

Alanın mevcut kullanımlarını ve ihtiyaç listesinin belirlenmesine yönelik değerlendirmeler sonucunda Van Yüzüncü Yı1 Üniversitesi Zeve Kampüsünde seçilen kıyı alanı ve yakın çevresi için öneri bir peyzaj plan hazırlanmış olup bu öneri peyzaj plan kararları stratejileri 3 başlık altında ele alınmıştır.

\subsubsection{Ekolojik Koruma Alanı}

Bütün dünyadaki kentleşme, hızlı nüfus artısı, sanayileşme, sürdürülebilir olmayan üretim ve tüketim alışkanlıkları ve doğal kaynakların tahribatı çarpıcı boyuta ulaşmanın önüne geçmek için doğa koruma çalışmaları başlatılmış, alanlar koruma altına alınmıştır. Ülkemizde halen koruma altına alınması gereken pek çok alan vardır (Dünya, 2012). Bu bağlamda kıyı kenar çizgisinin geniş olduğu alçak-basık kıyı tipi, içerisinde bulundurduğu sazlık alan, sürdürülebilirliğine imkan tanıyan mevcut doğal dokusu ile ekolojik koruma alanı olarak düzenlenme koşullarını barındırmaktadır (Şekil 5).

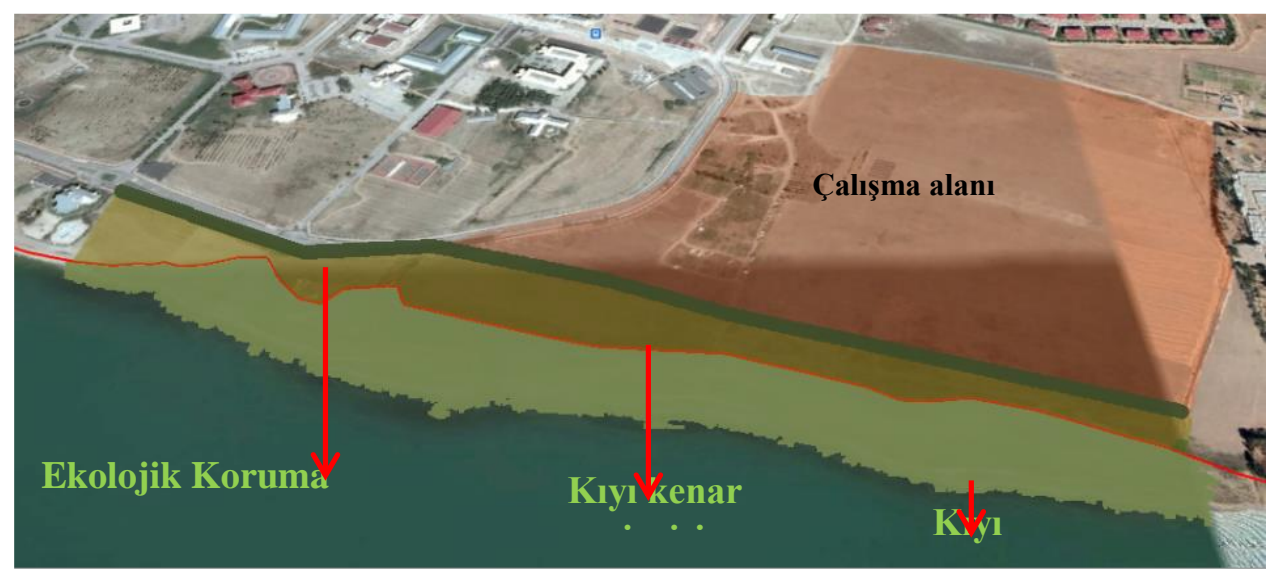

Şekil 5. Çalıma alanında ekolojik koruma sınırı

Figure 5. Ecological protection limit in the work area

Bu koşullar dâhilinde çalışma alanında: Mevcut yaya patika yolları üzerine yapılacak ana yol ile bağlantılı ahşap yürüyüş ve seyir iskeleleri; yaya hareketlerinin oluşturduğu ve mevcut dokunun da tahribatının engellemesine imkân tanıyan tasarım olarak öngörülmüştür. Alanın batısında kalan ve iskele tasarımının düşünüldüğü bu bölge, aynı zamanda kıyı kenar çizgisinin yola kadar gelebildiği, normal şartlarda sazlıkların yoğunlaştığı, dolayısıyla üzerinde herhangi bir kalıcı müdahaleye iznin olmadığı bir alandır. Kıyının geri kalan sazlık ve kumsal alanlarının ise herhangi bir müdahale olmadan, kampüs kullanıcılarına yönelik kuş gözlem evleri, foto-safari, doğa gezileri, dinlenme, seyir gibi çeşitli doğa aktiviteleri için öngörülmüştür (Şekil 6).

\subsubsection{Sosyo-Kültürel Alan/ Rekreasyon Alan}

Üniversite yaşantısında sosyal, kültürel etkinlikler için olanak sağlayan rekreasyon alanları hem öğrenciler hem çalışanlar ve aileleri için sosyal etkileşim açışından büyük önem taşımaktadırlar. Bu amaca yönelik çalışma 
alanında iklim faktörü göz önünde bulundurarak kapsamlı kafeterya (yarı kapalı, kış bahçeli) dışında, orta kısmında hâlihazırda yer alan, üniversite akademik personeline tahsis edilmiş, 50'şer $\mathrm{m}^{2}$ 'lik yaklaşık 60 adet hobi bahçeleri aktif olarak kullanılmaktadır. Ekilen organik sebze ve meyvelerden verim alındığı, mesai sonrası yaşam alanı haline gelen, içerisinde doğal yapı malzemeleri kullanılarak yapılmış küçük depo alanlarının da olduğu çevreyle barışık hobi bahçelerinin daha çok kullanıcıya hizmet etmesi amacıyla sayısının arttırılması, sınırını bulunduğu mevcut konumundan ekolojik koruma alanına kadar genişletilmesi de planlama dahilindedir. Çalışma alanı içerisinde, kıyıdan $100 \mathrm{~m}$ içeriye kadar olan ekolojik koruma bölgesi arkasında kalan belli bir bölgeyi kapsayan; konumu, işlevi ve doğal yapısı itibariyle kırsal, aktif ve değişken açık hava rekreasyon alanı öngörülmektedir (Şekil 6).

\subsubsection{Eğitim Platformu}

Üniversite öğrencilerinin derslikler dışında farklı mekanlarda öğrenimlerini geliştirmek ve sergilemek amacıyla açık havada farklı mekanların yaratılmasına planlamada yer verilmiştir. Bu amaçla Güzel Sanatlar Fakültesi, Eğitim Fakültesi, Mimarlık ve Tasarım Fakültesi öğrencilerin çalışmalarını sergileyebilecekleri alan oluşturulması öngörülmüştür. Bununla birlikte doğa bilimleri ile ilgili fakülte ve birimlerin doğal laboratuvar olarak kullanımına imkân sağlayan alanlar ayrılması uygun görülmüştür. Bu platform üniversite öğrencileri dışında kentteki lise, ortaokul ve ilkokul öğrencilerine de ilgili alanda öğrenimlerini geliştirmelerine yardımcı olacak niteliğinde olacaktır (Şekil 6).

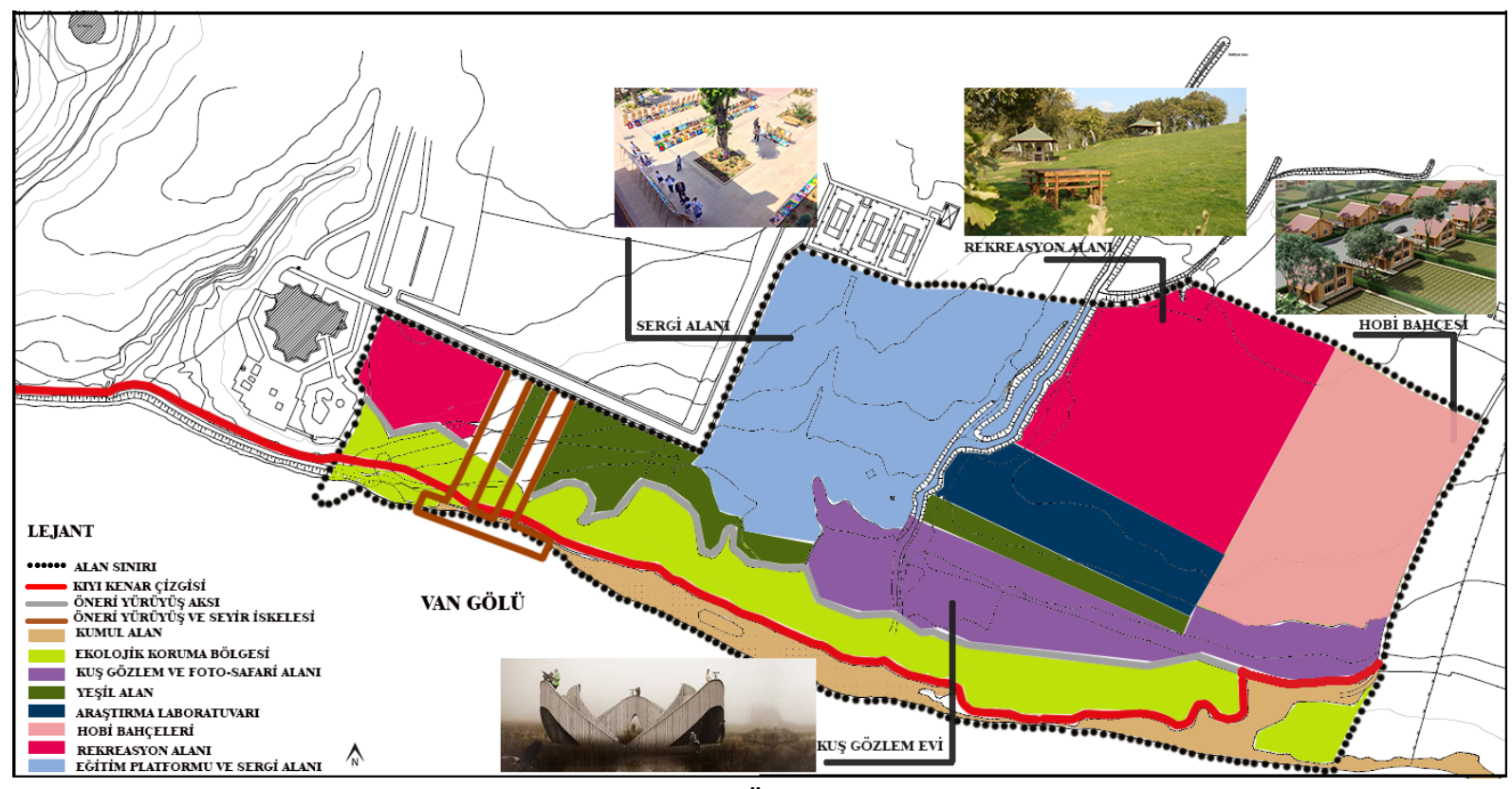

Şekil 6. Öneri peyzaj planı

Figure 6. Proposed landscape plan 


\section{SONUÇ}

Kıyı alanlarında yapılacak olan rekreasyonel planlama çalışmalarında kıyı kullanıcılarının serbest zaman aktivitelerini geçirebilecekleri alanlara ihtiyaç duyulmaktadır. Bu aktivite mekanları, planlanmadan önce kullanıcıya ilişkin analizlerin yapılması ve planlama aşamasında diğer karar verici birimlerle beraber değerlendirilmesi kıyının kullanıcı isteğine göre de planlanmasına katkı sağlayacaktır. İhtiyaca yönelik aktivite ve mekan önerilerinin getirilmesi, rekreasyonel eğilim ve taleplerin belirlenmesinde önemli bir etki oluşturacaktır (Özdemir Işık ve Demirel, 2014).

Kıyılar, kamuya ayrılmış alanlar olup nu alanlardan kamunun geniş oranda yararlanmasına yönelik düzenlemelerin yapılması, gereksinime cevap verecek belirli tesislerin sağlanması, bunların bakımı, onarımı ve denetimi bütünüyle bir yönetim işidir (Balık, 2017).

Van YYÜ Zeve Kampüsü Türkiye'de kıyısı bulunan sayılı kampüslerden olması nedeniyle önem taşımaktadır. Kıyısı olan bir kampüs alanının doğru bir stratejisiyle planlaması kampüsün, kıyısının ve ekosisteminin sürdürülebilirliği açısından büyük önem taşımaktadır. Bu çalışma, Van YYÜ Zeve Kampüsü kıyı alanında örnek çalışmayla farklı etnik ve sosyal yapılara, kültüre sahip öğrencilerin eğitim süreçleri boyunca ders dış1 zamanlarının büyük dilimini geçirdikleri mekânlar planlaması amacıyla yapılmıştır. Ön görülen bu peyzaj planı öğrenciler dışında kampüs alnındaki eğitimciler, çalışanlar ve aileleri için de sosyal etkileşim açışından büyük önem taşımaktadır.

$\mathrm{Bu}$ çalışmada mevcut alandaki fiziki, çevresel açıdan mevcut durum analizi yapılmış, kıyı ve alan kullanımlarına ilişkin gözlemlerde bulunulmuş, doğayla doğrudan veya dolaylı ilişki halindeki alanlar araştırılmıştır. Çıkan sonuçlardan elde edilen çözümlemelerden yola çıkarak açık ve kapalı alan planlamaları, kıyı planlama anlayışına uyumlu, sürdürülebilir bir yaklaşımla öngörülmüştür. Bu bağlamda Van Yüzüncü Yıl Üniversitesi Zeve Kampüsünde seçilen kıyı alanı ve yakın çevresi için; ekolojik koruma alanı, sosyo-kültürel alan/ rekreasyon alanı, eğitim platformunu içerecek şekilde 3 başlık altında öneri peyzaj plan hazırlanmıştır. Böylelikle daha fazla sayıda bireye hizmet eden fakat mevcut doğal alana en az müdahale amacı güden bir planlama anlayışını desteklemek amaçlanmıştır.

\section{KAYNAKÇA}

Acarlar, M., Bilgin, E., Elibol, E., Erkal., T., Gedik, İ., (1991). Van gölü doğu ve kuzeyinin jeolojisi. MTA Genel Müdürlüğü, Arşiv No: 1061, Ankara.

Açıksöz, S., Cengiz, B., Bekçi, B., Cengiz, C., Cengiz Gökçe, G., (2014). Üniversite Yerleşkelerinde açık ve yeşil alan sisteminin planlanması ve yönetimi: Bartın Üniversitesi Kutlubey-Yazıcılar Yerleşkesi. Kastamonu Üniversitesi Orman Fakültesi Dergisi, 14(2): 222-236.

Akın, M. K., Akın, M., Akkaya, İ., Özvan, A., Üner, S., Selçuk, L., \& Tapan, M. (2015). Mikrobölgeleme Çalışmasına Altlık Oluşturmak Üzere Van Yüzüncü Yı1 Üniversitesi Kampüs Zemininin Dinamik Özelliklerinin Belirlenmesi. Geological Engineering Journal/Jeoloji Mühendisligi Dergisi, 39(1). 
Aksu, A., Yılmaz, H., (2018). Atatürk Üniversitesi Merkezi açık-yeşil alandaki fiziki değişim memnuniyetinin belirlenmesi. Iğdır Üniversitesi Fen Bilimleri Enstitüsü Dergisi, 8(2): 231-237. Aşur F., (2017). Van Kenti Yakın Çevresi Kıyı Alanı Örneğinde Sulak Alanlar ve Görsel Peyzaj Kalite Değerlendirmesi. Türk Tarım ve Doğa Bilimleri Dergisi.4(4).506-515.

Aşur, F., \& Alphan, H., (2018). Van Gölü Güney Kıyı alanlarında yerleşim alan kullanım değerlendirmesi ve görsel analiz yaklaşımları. Iğdır Üniversitesi Fen Bilimleri Enstitüsü Dergisi, 7(4), 223-233.

Atalay İ., (2005). Genel Fiziki Coğrafya, 6. Baskı, Meta Basım Matbaacılık Hizmetleri, İzmir.

Altıntaş, V. 2015. Türkiye'de Üniversitelerin Bölgesel ve Yerel Gelişmeye Etkileri. Yayınlanmamış Yüksek Lisans Tezi, İstanbul Teknik Üniversitesi, Türkiye.

Balık, İ., (2017). Ordu'da Kıyı Alanı Kullanımı ve Denizel Ekosisteme Etkileri. Kent Kültürü ve Yönetimi Hakemli Elektronik Dergi, 10,29/1.

Bekci, B., Taşkan, G., Bogenç, Ç., (2013). The effect of courtyard designs on young people, Which have been made according to different function alpreferences: Bartın university (Turkey), Journal of Food, Agriculture\& Environment, Vol. 11(3\&4):1804-1813.

Booth, N., (1990). Basic Elements of Landscape Architectural Design, WavelandPress, Inc. Illinois, USA, 315.

Çetinkaya, G., Uzun, O., (2014). Peyzaj Planlama, Birsen Yayınevi, Ankara.

Çorbacı, Ö. L., Gülez, S., Topay, M. 2005. ZKÜ Merkez Kampüsü Isı Merkezi Yolu ve Çevresi Peyzaj ve Rekreasyon Projesi. ZKÜ Bartın Orman Fakültesi Dergisi 7, 24-34.

Dünya, N., (2012). Doğa Koruma Alanlarından Milli Parklarda Baraj ve Hidroelektrik Santrali Uygulamalarının İncelenmesi: Munzur Vadisi Milli Parkı Örneği. İstanbul Teknik Üniversitesi Fen Bilimleri Enstitüsü. Yüksek Lisans Tezi, İstanbul.

Erçevik, B., Önal, F., (2011). Üniversite kampüs sistemlerinde sosyal mekan kullanımları. Megaron, 6(3): 151-161.

Erkman, U., (1990). Büyüme ve Gelişme Açısından Üniversite Kampüslerinde Planlama ve Tasarım Sorunları, İ.T.Ü. Mimarlık Fakültesi Baskı Atölyesi.

Karaşah, B., Muhacir, E. S. A., Sarı, D., \& Yaman, Y. K. (2016). Artvin Çoruh Üniversitesi Seyitler Yerleşkesi Peyzaj Tasarımı. İnönü Üniversitesi Sanat ve Tasarım Dergisi, 6(13).

Koçyiğit, A., (2013). New field and seismic data about the intraplate strike-slip deformation in Van region, East Anatolian Plateau, Turkey. Journal of Asian Earth Sciences, 62, 586-605.

Ortaçesme, V. (2007). Avrupa Peyzaj Sözleşmesi bağlamında peyzaj planlama. Avrupa Peyzaj Sözleşmesinin Uygulanması Yolunda Türkiye Sempozyumu, Ankara, 86-93. 
Özdemir Işık, B., Demirel, Ö., (2014). Kıyı Kullanıcıların Kıyı Alanı Rekreasyon Planlama Kararları Üzerindeki Etkisi: Trabzon Kıyı Bandı Örneği. İnönü Üniversitesi Sanat ve Tasarım Dergisi. 4(10): 111.

Selçuk, L. (2003). Yüzüncü Yı1 Üniversitesi Zeve Kampüsü yerleşim alanının mühendislik jeolojisi. Yüzüncü Yıl Üniversitesi Fen Bilimleri Enstitüsü Jeoloji Mühendisliği Anabilim Dalı, Van, Yüksek Lisans Tezi, $150 \mathrm{~s}$ (yayımlanmamış).

URL 1, (2020). Boğaziçi Üniversitesi Sürdürülebilir Yeşil Kampüs Uygulamaları Komisyonu. https://yesilkampus.boun.edu.tr/tr/content/bilimsel-arastirma TR/Content/Genel/Yonetim/Kurul_ve_Komisyonlar/Surdurulebilir_Yesil_Kampus_Uygulamalari_ Komisyonu, Erişim: 03.02.2020.

URL 2, (2020). http://wikimapia.org/8518174/tr/Van-Y\%C3\%BCz\%C3\%BCnc\%C3\%BC-Y\%C4\%B11\%C3\%9Cniversitesi-Zeve-Yerle\%C5\%9, Erişim Tarihi: 25,02, 2020.

URL 3,(2020). http://van.kutuphane.gov.tr/TR-183896/cografiyapisi.html\#: :text=Van\%20ilinde\%20kara\%20iklimi\%20h\%C3\%BCk\%C3\%BCm,0\%C2\%B0C\%20alt \%C4\%B1nda\%20ge\%C3\%A7er. Erişim: 08.10.2020.

Yılmaz, H., Yılmaz, S., (2000). Peyzaj Mimarlığında Tasarım Süreci ve Proje Örnekleri, Atatürk Üniversitesi Ziraat Fakültesi Ders Yayınları, No:218, Sayfa:106, Erzurum

Yılmaz, M., (2014). Van Yüzüncü Y1l Üniversitesi Çevresindeki Arazi Kullanımına Eleştirel Bir Bakış..Ankara Üniversitesi TUCAUM VIII. Coğrafya Sempozyumu, 255-261.

Yılmaz, T., Zırhlığlu, B., Olgun, R., (2013). Üniversite Yerleşke Alanlarında Su Kullanımlarının İncelenmesi: Akdeniz Üniversitesi Örneği. İnönü Üniversitesi Sanat ve Tasarım Dergisi 7,13-21.

Yuca, N., (2019). Atatürk Üniversitesi Merkez Yerleşkesinin Dış Mekan Fiziki Dokusunun Öğrenci Kullanıcı Memnuniyetinin Belirlenmesi. Atatürk Üniversitesi Fen Bilimleri Enstitüsü. Yüksek Lisans Tezi, Erzurum. 